\title{
Oestrogenic activity of the hop phyto-oestrogen, 8-prenylnaringenin
}

\author{
S. Milligan¹, J. Kalita1, V. Pocock1 , A. Heyerick², L. De Cooman², \\ H. Rong ${ }^{2}$ and D. De Keukeleire ${ }^{2}$ \\ ${ }^{1}$ Endocrinology and Reproduction Research Group, School of Biomedical Sciences, \\ King's College, Guy's Campus, London SE1 1UL, UK; and ${ }^{2}$ Ghent University, \\ Laboratory of Pharmacognosy and Phytochemistry, Faculty of Pharmaceutical Sciences, \\ Harelbekestraat 72, B-9000 Ghent, Belgium
}

The female flowers of the hop plant (hop cones) are used as a preservative and as a flavouring agent in beer. A novel phyto-oestrogen, 8-prenylnaringenin, was recently identified in hops and this study was undertaken to characterize the oestrogenic activity of this compound using a combination of in vitro and in vivo assays. Natural and semi-synthetic 8-prenylnaringenin showed similar bioactivities both in a yeast screen transfected with the human oestrogen receptor and in oestrogen-responsive human Ishikawa Var-I cells. 8-Prenylnaringenin showed comparable binding activity to both oestrogen receptor isoforms (ER $\alpha$ and $E R \beta)$. 8-Prenylnaringenin extracted from hops contains similar amounts of both $(R)$ - and $(S)$ - enantiomers, indicating that the compound is normally formed non-enzymatically. Both enantiomers showed similar bioactivity in vitro and similar binding characteristics to $E R \alpha$ and $E R \beta$. The oestrogenic activity of 8-prenylnaringenin in vitro was greater than that of established phyto-oestrogens such as coumestrol, genistein and daidzein. The high oestrogenic activity was confirmed in an acute in vivo test using uterine vascular permeability as an end point. When the compound was given to ovariectomized mice in their drinking water, oestrogenic stimulation of the vaginal epithelium required concentrations of $100 \mu \mathrm{g} \mathrm{ml}^{-1}$ (about 500-fold greater than can be found in any beer).

\section{Introduction}

The female flowers (cones) of hops (Humulus lupulus L.) have been used for centuries as a preservative and as a flavouring agent in beer. Over the years, a recurring suggestion has been that hops have a powerful oestrogenic activity and that beer may also be oestrogenic. Hop baths have been used for the treatment of gynaecological disorders and hop extracts have been reported to be effective in reducing hot flushes in menopausal women. In times when hops were picked by hand, menstrual disturbances among female pickers were reportedly common. Although the oestrogenic activity of hops was attributed to xanthohumol, a prenylated chalcone, this was without any experimental support (Verzele, 1986). Initial scientific studies of the oestrogenic activity of hops proved contradictory: some early investigations (Koch and Heim, 1953; Zenisek and Bednar, 1960; Hesse et al., 1981) reported that the oestrogenic activity of hops was very high, but other investigations (Feneslau and Talalay, 1973) found no indication of oestrogenicity. These discrepancies over the potential oestrogenic activity of hops are likely to have been due to the variable nature of the extracts and the variety of assays used. However, after bioassay-guided fractionation

Email: Stuart.Milligan@kcl.ac.uk of hop extracts, Milligan et al. (1999) identified a novel phyto-oestrogen, 8-prenylnaringenin (Fig. 1). Using both a yeast-based screen to detect oestrogenic activity and a receptor binding assay using rat uterine cytosol, 8prenylnaringenin appeared to be one of the most potent phyto-oestrogens, and had an oestrogenic activity considerably greater than that of phyto-oestrogens such as genistein and daidzein (Fig. 1).

There is considerable interest in whether human exposure to phyto-oestrogens has any health risks or benefits (Knight and Eden, 1996; Cassidy and Milligan, 1998). The secretions of the lupulin glands present in the female hop flowers contain predominantly bitter acids and hop oil constituents, essential in brewing, along with 8-prenylnaringenin and other prenylflavonoids. 8-Prenylnaringenin can be found in many beers at concentrations of up to $0.24 \mathrm{mg} \mathrm{l}^{-1}$ (Stevens et al., 1999; Rong et al., 2000). There may also be significant exposure of women to 8-prenylnaringenin from a number of commercially available herbal preparations, including those claiming breast enlargements (Sauer and Coldham, 2001). In view of such exposure of humans to 8-prenylnaringenin and its apparent high oestrogenic activity, the present study was undertaken to characterize the nature of the oestrogenic activity of this compound using a combination of in vitro and in vivo assays, and to examine the binding of 8prenylnaringenin to the two isoforms of the oestrogen 


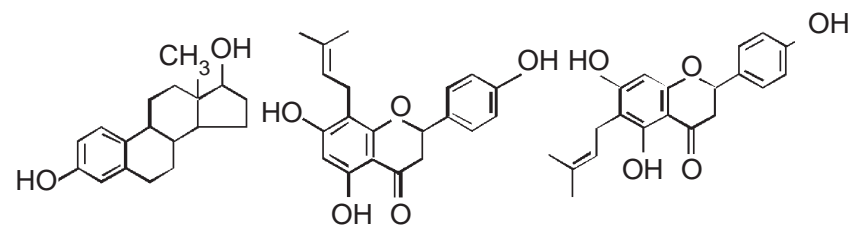

Oestradiol 8-Prenylnaringenin 6-Prenylnaringenin

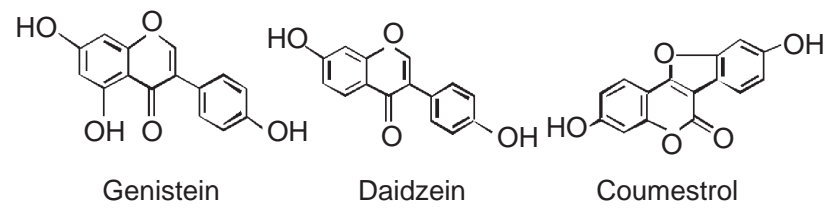

Fig. 1. Structures of oestradiol and established phyto-oestrogens.

receptor (ER $\alpha$ and $E R \beta)$. In addition, as 8-prenylnaringenin contains a chiral centre at $\mathrm{C}(2)$ and can exist in both an $(R)$ and (S)-form, the oestrogenic activity of both enantiomers was investigated.

\section{Materials and Methods}

\section{Compounds}

Oestradiol, oestriol, genistein (4',5,7-trihydroxyisoflavone) and daidzein (4',7-dihydroxyisoflavone) were supplied by Sigma Chemical Co. Ltd, Poole. Coumestrol (3,9dihydroxy-6H-benzofuro-[3,2-c] [1] benzopyran-6-one) was from Acros Organics, NJ and formononetin (7-hydroxy-4'methoxyisoflavone) from Extrasynthèse, Genay. The antioestrogen ICI 182,780 was a gift from A. Wakeling (Zeneca Pharmaceuticals, Macclesfield).

\section{Polyphenolic extracts of hops}

Dry hop cones $(5 \mathrm{~g})$ were extracted consecutively under reflux and nitrogen with petroleum ether $(200 \mathrm{ml}, 30 \mathrm{~min}$; $125 \mathrm{ml}, 60 \mathrm{~min} ; 50 \mathrm{ml}, 60 \mathrm{~min})$ and $n$-hexane $(125 \mathrm{ml}$, $60 \mathrm{~min}$, three times). All fractions were discarded and the residue was extracted under reflux and nitrogen with $80 \mathrm{ml}$ methanol: water $(3: 1 ; \mathrm{v} / \mathrm{v})$ for $2 \mathrm{~h}$ (three times). This extract was partitioned with petroleum ether $(100 \mathrm{ml}$, twice) and $n$ hexane $(100 \mathrm{ml}$, twice), and the aqueous methanolic extract was adjusted to $100 \mathrm{ml}$. Individual compounds were isolated by semi-preparative HPLC (Kontron pump system 32X, photodiode array detector 440, data system 450-MT2/DAD series) using a Biosil C18 HL 90-10 (Bio-Rad, Nazareth) $10 \times 250 \mathrm{~mm}(10 \mu \mathrm{m})$ column and a gradient of solvent $\mathrm{A}$ $(0.05 \%(\mathrm{v} / \mathrm{v})$ formic acid in water) and solvent B $(5 \%(\mathrm{v} / \mathrm{v})$ acetonitrile in methanol). Gradient profile: $0-2 \mathrm{~min}$ : isocratic $45 \% \mathrm{~B}$ in $\mathrm{A} ; 2-32 \mathrm{~min}: 45 \% \mathrm{~B}$ in $\mathrm{A}$ to $95 \% \mathrm{~B}$ in $\mathrm{A} ; 32-37$ min: $95 \%$ in $A ; 37-45$ min: $95 \% B$ in $A$ to $45 \% B$ in $A$; 45-47 min: $45 \%$ B in A. Retention times of isoxanthohumol, 8-prenylnaringenin, 6-prenylnaringenin and xanthohumol were 15.1, 19.4, 23.7 and 26.4 min, respectively.

\section{Preparation of 8-prenylnaringenin}

Dry hop cones $(300 \mathrm{~g})$ were immersed in dichloromethane (2 I) for $2 \mathrm{~h}$. The extract was filtered and the solvent evaporated. After the addition of $300 \mathrm{ml} 70 \%(\mathrm{v} / \mathrm{v})$ aqueous methanol, the solution was maintained at $-20^{\circ} \mathrm{C}$ overnight. The precipitate was separated; the filtrate was concentrated to dryness; the residue was redissolved in $50 \mathrm{ml}$ of $5 \%(\mathrm{v} / \mathrm{v})$ ethanolic potassium hydroxide; and the solution was refluxed for $30 \mathrm{~min}$ under nitrogen. After cooling to room temperature, the reaction mixture was poured into $200 \mathrm{ml} 5 \%(\mathrm{v} / \mathrm{v}) \mathrm{HCl}$ and extracted twice with ethyl acetate. The combined extracts were dried $\left(\mathrm{Na}_{2} \mathrm{SO}_{4}\right)$ and concentrated. The residue was purified by column chromatography (Silica gel, Merck grade 9385, $60 \AA$ ) using ethyl acetate: cyclohexane (9:1) to give $780 \mathrm{mg}$ of isoxanthohumol $(80 \%)$. A cooled solution of boron trichloride $(650 \mu \mathrm{l}$, $0.65 \mathrm{mmol}$ ) in dichloromethane was added to a stirred solution of isoxanthohumol $(15 \mathrm{mg}, 0.04 \mathrm{mmol})$ in acetonitrile $(1 \mathrm{ml})$ at $-78^{\circ} \mathrm{C}$. The reaction mixture was allowed to warm up to $0^{\circ} \mathrm{C}$ over a period of $3 \mathrm{~h}$, and was then poured on to ice and extracted with ethyl acetate. The extract was washed with water, saturated with $\mathrm{NaCl}$, dried over $\mathrm{Na}_{2} \mathrm{SO}_{4}$ and concentrated to dryness. After purification by column chromatography (Silica gel; ethyl acetate: cyclohexane 8:2), $7.6 \mathrm{mg}$ of 8-prenylnaringenin was obtained (53\%).

\section{Separation of (R)- and (S)-8-prenylnaringenin}

The enantiomers of the prenylated hop flavanones, isoxanthohumol, 8-prenylnaringenin, and 6-prenylnaringenin were separated by chiral liquid chromatography (triacetyl cellulose (TAC), $4.1 \times 250.0 \mathrm{~mm}$, prepared in the Laboratory of Separation Sciences, Department of Organic Chemistry, Ghent University) using methanol as eluent at a flow rate of $0.8 \mathrm{ml} \mathrm{min}{ }^{-1}$. UV detection was at $280 \mathrm{~nm}$. The fractions containing the enantiomers of 8-prenylnaringenin were collected by semi-preparative chiral HPLC and the solvent was evaporated. (R)-8-prenylnaringenin and (S)-8-prenylnaringenin were dissolved in methanol $\left(3.4 \mathrm{mg}(10 \mathrm{ml})^{-1}\right.$ and $3.3 \mathrm{mg}(10 \mathrm{ml})^{-1}$, respectively) and their CD spectra were recorded on an Olis DSM 10 CD spectrophotomer (Olis, Bogart, GA; $1 \mathrm{mmol} \mathrm{I}^{-1}$ in $\mathrm{MeOH}$ ).

\section{Determination of oestrogenic bioactivity in vitro}

Hop extracts and pure compounds were diluted in ethanol. Aliquots $(20 \mu \mathrm{l})$ were added to individual wells in a 96-well plate and the ethanol was evaporated. Oestrogenic activity was determined in two separate in vitro bioassays. The first bioassay used a human endometrial cell line, Ishikawa Var I (a gift from E. Gurpide, Mount Sinai School of Medicine, NY) that responds to oestrogenic stimulation by a marked increase in alkaline phosphatase activity (Markiewicz et al., 1993). Cells $\left(2.5 \times 10^{4}\right.$ cells per well in $100 \mu \mathrm{l}$ ) were plated in 96-well plates in oestrogen-free basal medium (EFBM; phenol red-free Ham's F12 and Dulbecco's modified eagle's medium $(1: 1)$, and $5 \%(\mathrm{v} / \mathrm{v})$ charcoal- 
stripped FBS). The anti-oestrogen ICI 182,780 was used in some wells at a final concentration of $0.16 \mu \mathrm{mol} \mathrm{I}^{-1}$ to evaluate the specificity of the response. Alkaline phosphatase activity was determined after $72 \mathrm{~h}$ by monitoring the hydrolysis of $p$-nitrophenyl phosphate to $p$-nitrophenol at $405 \mathrm{~nm}$.

Oestrogenic bioactivity was also studied using an oestrogen-inducible yeast screen (Saccharomyces cerevisiae) expressing the human oestrogen receptor and containing expression plasmids carrying oestrogen-responsive sequences controlling the reporter gene lac- $Z$ (encoding the enzyme $\beta$-galactosidase; a gift from J. Sumpter, Brunel University). Oestrogenic activity was determined from the enzymatic hydrolysis of chlorophenol red $\beta$-D-galactopyranoside by monitoring the absorbance at $540 \mathrm{~nm}$ (Routledge and Sumpter, 1996).

\section{Receptor binding}

Oestrogen receptor binding activity was studied using recombinant human oestrogen receptor $\alpha$ and $\beta$ (ER $\alpha$ and ER $\beta$ ) obtained from PanVera Corporation (Madison, WI). Dilutions of the test compounds were incubated in $100 \mu \mathrm{l}$ buffer (10 mmol Trizma preset crystals $\mathrm{I}^{-1}(\mathrm{pH} 7.5), 10 \%$ glycerol, $2 \mathrm{mmol}$ DL-dithiothreitol (DTT) I-1, $1 \mathrm{mg} \mathrm{BSA} \mathrm{ml}^{-1}$ ) with $15 \mathrm{nmol}\left[2,4,6,7{ }^{3} \mathrm{H}\right]$-oestradiol I-1 $\left(84.0 \mathrm{Ci} \mathrm{mmol} \mathrm{I}^{-1}\right.$; Amersham Life Science, Amersham) and ER (1.5 nmol $\left.\mathrm{I}^{-1}\right)$. The mixture was incubated overnight at $4^{\circ} \mathrm{C}$, and free and bound hormone were separated using $100 \mu \mathrm{l} 15 \%(\mathrm{w} / \mathrm{v})$ hydroxylapatite slurry (in $50 \mathrm{mmol}$ Tris- $\mathrm{HCl} \mathrm{I-1,} \mathrm{pH} 7.4$, $\left.1 \mathrm{mmol} \mathrm{EDTA} \mathrm{I}^{-1}\right)$. After three washes in buffer (ER $\alpha$ :

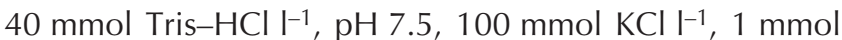
EDTA I $^{-1}$, $1 \mathrm{mmol}^{\mathrm{E}} \mathrm{mTA} \mathrm{I}^{-1}$; ER $\beta$ : $40 \mathrm{mmol}^{\mathrm{T}}$ is $-\mathrm{HCl} \mathrm{I}^{-1}$, $\mathrm{pH}$ 7.5), the slurry was extracted with two washes of $200 \mu \mathrm{l}$ ethanol and the radioactivity in the extracts was determined.

\section{In vivo assays}

The relative potency of oestrogenic compounds in vivo depends on a number of factors, including the route of administration and the nature of the response monitored. Estimates of oestrogenic potency are affected markedly depending on the nature of the in vivo bioassay used. Therefore, two in vivo assays were used: the first assay was based on the rapid response of the uterine vasculature to oestrogenic stimulation (Arvidson, 1977; Milligan et al., 1998). The second assay was based on the uterotrophic response and mitotic responses of the uterine and vaginal epithelium. In both assays, female Swiss albino mice (A. Tuck \& Son Ltd, Battlesbridge, Essex), approximately 2-3 months of age and weighing 20-25 g, were maintained under constant conditions of lighting (lights on from 06:00 h to $18: 00 \mathrm{~h})$ and temperature $\left(21 \pm 1^{\circ} \mathrm{C}\right)$, and fed on a pelleted diet (Economy Rodent Maintenance, Essex) ad libitum. Animal care was undertaken according to UK Home Office guidelines. All experiments were performed on ovariectomized animals. Ovariectomies were performed under tribromoethanol anaesthesia at least 2 weeks before the start of each experiment.

\section{Acute uterine vascular response}

In the assay based on the rapid response of the uterine vasculature to oestrogenic stimulation, a quantitative index of the vascular permeability was obtained from the leakage of radiolabelled albumin from the circulation (Arvidson, 1977; Milligan et al., 1998). Three and a half hours after s.c. injection of the test substance (in $0.1 \mathrm{ml}$ saline), $0.5 \mu \mathrm{Ci}$ 125 -labelled human serum albumin $(50 \mu \mathrm{l})$ was injected into the jugular vein of the mice anaesthetized with tribromoethanol. After 30 min, a blood sample was taken from the suborbital canthal sinus with a heparinized capillary pipette and the animals were killed by cervical dislocation. The blood sample was centrifuged for $5 \mathrm{~min}$ at $1000 \mathrm{~g}$ to provide a $100 \mu \mathrm{l}$ plasma sample. The uteri and a sample of thigh muscle were removed, washed briefly in saline and then weighed. The radioactivity in the uterus, plasma sample and muscle was determined. Previous studies on the uterus (Arvidson, 1977; Milligan et al., 1998) have indicated that the blood volume of the uterus is very much smaller than the albumin space (after a circulation time of $30 \mathrm{~min}$ ) and that the extravascular albumin space is the major determinant of the total tissue albumin space. The tissue-specific extravascular albumin volume (EAV) was expressed as a ratio of [ $\left.{ }^{125} \mathrm{I}\right]$ c.p.m. $\mathrm{mg}^{-1}$ of tissue: $\left[{ }^{125} \mathrm{I}\right]$ c.p.m. $\mu^{-1}$ plasma and used as an index of tissue vascular permeability. Each day s.c. injections of $\mathrm{ICI} 182,780$ $\left(100 \mu \mathrm{g}(100 \mu \mathrm{l})^{-1}\right.$ arachis oil) were given to some animals for 4 days before administration of 8-prenylnaringenin or oestradiol to investigate whether the vascular responses could be blocked by an anti-oestrogen.

\section{In vivo assays of vaginal and uterine mitosis and uterotrophic response}

The oestrogenic potency of 8-prenylnaringenin was tested after continuous administration in the drinking water by monitoring the uterotrophic response and cell mitoses in the vaginal and uterine epithelia. Mice were allocated randomly ( $n=6$ per treatment) to one of the following treatment groups: (i) $100 \mathrm{ng}$ oestrogen $\mathrm{ml}^{-1}$, (ii) 100, 20, 4 and $0.8 \mu \mathrm{g}$ 8-prenylnaringenin $\mathrm{ml}^{-1}$ or (iii) a drinking water control of $1 \%(\mathrm{v} / \mathrm{v})$ Tween 80 (polyoxyethylenesorbitan monooleate) in water; the treatment bottles were weighed and replaced each day. Uterine and vaginal cell proliferation were assessed $72 \mathrm{~h}$ after the start of treatment. Mice were injected i.p. with $0.1 \mathrm{ml}$ colchicine $(\mathrm{BDH}$, Poole) in saline $\left(1 \mathrm{mg} \mathrm{ml}^{-1}\right) 2 \mathrm{~h}$ before they were killed. The uterine horns were removed, blotted on tissue and weighed. The vaginae and uterine horns were fixed in Bouin's solution, embedded in paraffin wax, cut into serial sections $(5 \mu \mathrm{m})$, and stained with haematoxylin and eosin. The number of cells undergoing mitosis in the entire uterine luminal epithelium and random areas of the basal layer of the vaginal epithelium were counted from four or more sections (at least 1000 cells 

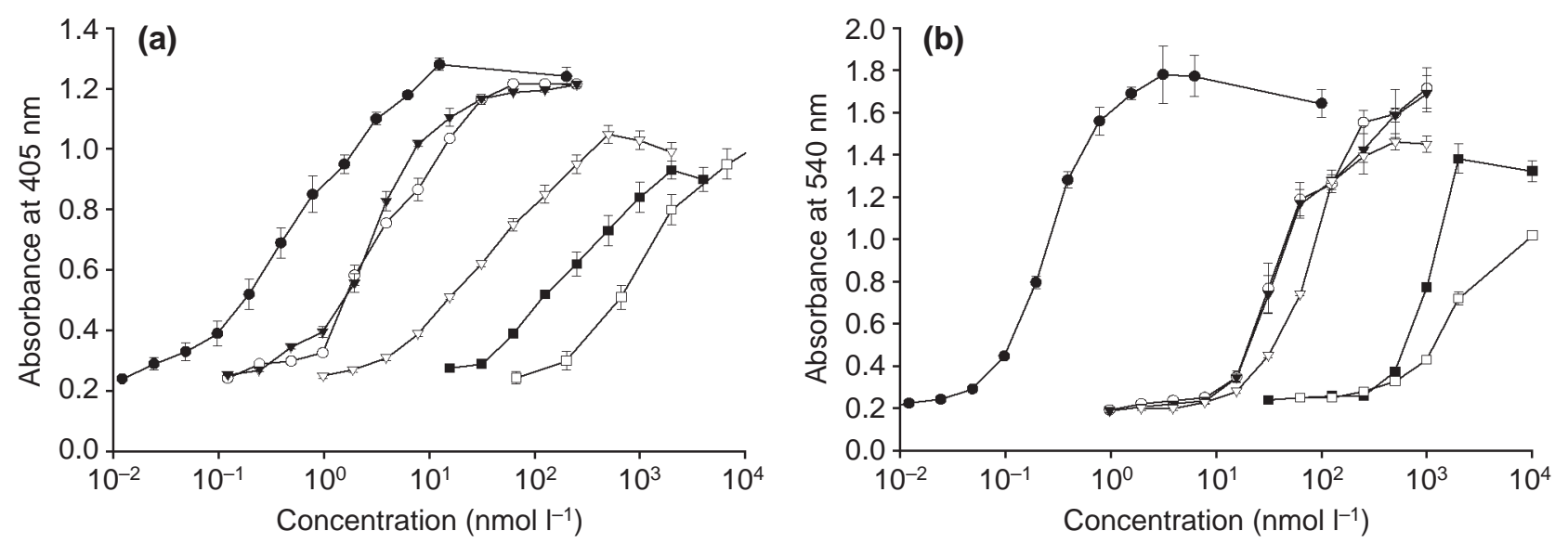

Fig. 2. Relative oestrogenic activity of oestradiol (-), 8-prenylnaringenin (semi-synthetic; $\bigcirc$ ), 8-prenylnaringenin (natural; $\mathbf{\nabla}$ ) and other phyto-oestrogens (coumestrol $(\nabla)$, genistein $(\mathbf{\square})$, daidzein $(\square)$ ) in (a) Ishikawa Var I cells and (b) yeast screen bearing the human oestrogen receptor. Results are means $\pm \mathrm{SEM} ; n=6$ wells per point. Where no error bars are visible, the errors were smaller than the symbols.

counted for each tissue). The mitotic index (\% mitosis) was calculated by the total number of mitoses divided by the total number of cells counted $\times 100$.

\section{Statistical analysis}

Results were expressed as mean \pm SEM and analysed initially using one-way ANOVA and the Tukey's multiple comparison test. Data that did not pass either the normality test or the equal variance test were analysed using the Kruskal-Wallis one-way analysis on Ranks followed by Dunn's all pairwise multiple comparison test.

\section{Results}

\section{Comparison of the oestrogenic activity of natural and semi-synthetic 8-prenylnaringenin}

Natural (purified from hops) and semi-synthetic 8prenylnaringenin showed equivalent oestrogenic activity in both the Ishikawa Var-I assay and the yeast screen (Fig. 2). The $\mathrm{EC}_{50}$ values for oestradiol, semi-synthetic 8-prenylnaringenin and natural 8-prenylnaringenin were $0.82 \pm 0.01$, $4.24 \pm 0.01$ and $4.41 \pm 0.02 \mathrm{nmol} \mathrm{I}^{-1}$, respectively, in the Ishikawa assay and $0.33 \pm 0.01,43.7 \pm 1.4$ and $40.0 \pm 1.3 \mathrm{nmol} \mathrm{I}^{-1}$, respectively, in the yeast screen. The responses of Ishikawa Var-I cells were blocked completely by $10 \mu \mathrm{mol} \mathrm{ICl} 182,780 \mathrm{I}^{-1}$ (data not shown). The in vitro oestrogenic potency of 8-prenylnaringenin was greater than that of other established phyto-oestrogens in both assays. The $\mathrm{EC}_{50}$ values for oestradiol, 8-prenylnaringenin, 6prenylnaringenin, coumestrol, genistein and daidzein were $0.8,4,500,30,200$ and $1500 \mathrm{nmol} \mathrm{I}^{-1}$, respectively, in the Ishikawa cell assay, and 0.3, 40, > 4000, 70, 1200 and $2200 \mathrm{nmol} \mathrm{I}^{-1}$, respectively, in the yeast screen.

\section{The oestrogenic activity of $(R)$ - and (S)-8-prenylnaringenin}

Resolution of 8-prenylnaringenin by chiral HPLC revealed approximately equal amounts of the enantiomers in both natural and semi-synthetic 8-prenylnaringenin (Fig. 3a). The circular dichroism spectrum of peak ' $A$ ' was almost identical to that reported for (S)-naringenin (Gaffield, 1970), whereas the spectrum of peak ' $\mathrm{B}$ ' was the reflection of ' $\mathrm{A}$ '. The two enantiomers showed similar oestrogenic activity in both the recombinant yeast cell and Ishikawa Var-I bioassays (Fig. 4c). The enantiomers of 8-prenylnaringenin competed strongly with oestradiol for binding to both $E R \alpha$ and $E R \beta$ with a relative binding affinity of about 0.01 (oestradiol $=1$ ) (Fig. 4a,b).

\section{The oestrogenic activity of 8-preny/naringenin in vivo}

The uterine vascular responses to oestradiol, oestriol and the phyto-oestrogens are shown (Fig. 4d). Oestriol was only slightly less effective than oestradiol in inducing a rapid increase in uterine vascular permeability within $4 \mathrm{~h}$ of administration, but both 8-prenylnaringenin and coumestrol were considerably less potent $(<1 \%$ relative to oestradiol). The dose-response relationship for 8-prenylnaringenin was similar to that of coumestrol, and a large stimulatory effect was produced by 100 nmoles 8-prenylnaringenin. The amount of genistein required to produce the same effect was at least ten-fold greater. The administration of daidzein produced no detectable uterine vascular response at the doses used. The responses to 8-prenylnaringenin and oestradiol were blocked completely by prior treatment of the animals with the anti-oestrogen ICI 182,780 (Table 1). There were no changes in the vascular permeability of the muscle tissue control in any treatment group.

\section{In vivo assays of vaginal and uterine mitosis and uterotrophic response}

The addition of 8-prenylnaringenin or oestradiol to the drinking water of mice is an effective way of providing continuous, non-invasive oral administration of these 
(a)

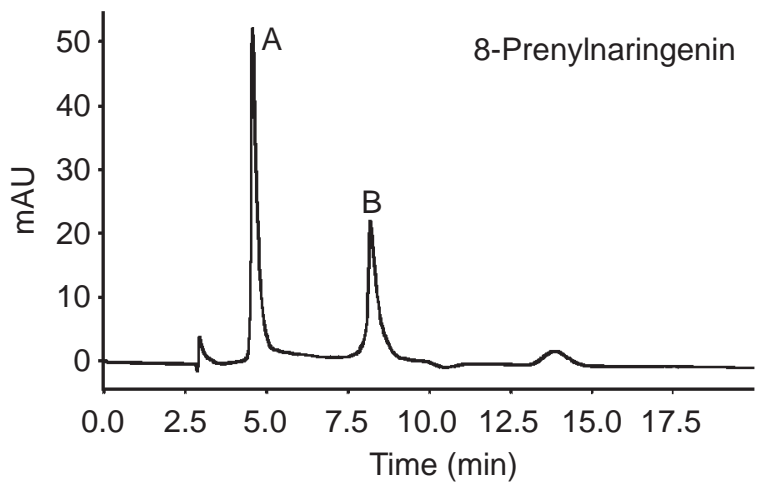

(b)<smiles>CC(C)CCc1c(O)cc(O)c2c1O[C@H](c1ccc(O)cc1)CC2=O</smiles>

(S)-8-Prenylnaringenin

(R)-8-Prenylnaringenin

Fig. 3. (a) Enantioseparation of (S)-8-prenylnaringenin (peak A) and (R)-8-prenylnaringenin (peak B). (b) Absolute structures of the enantiomers.
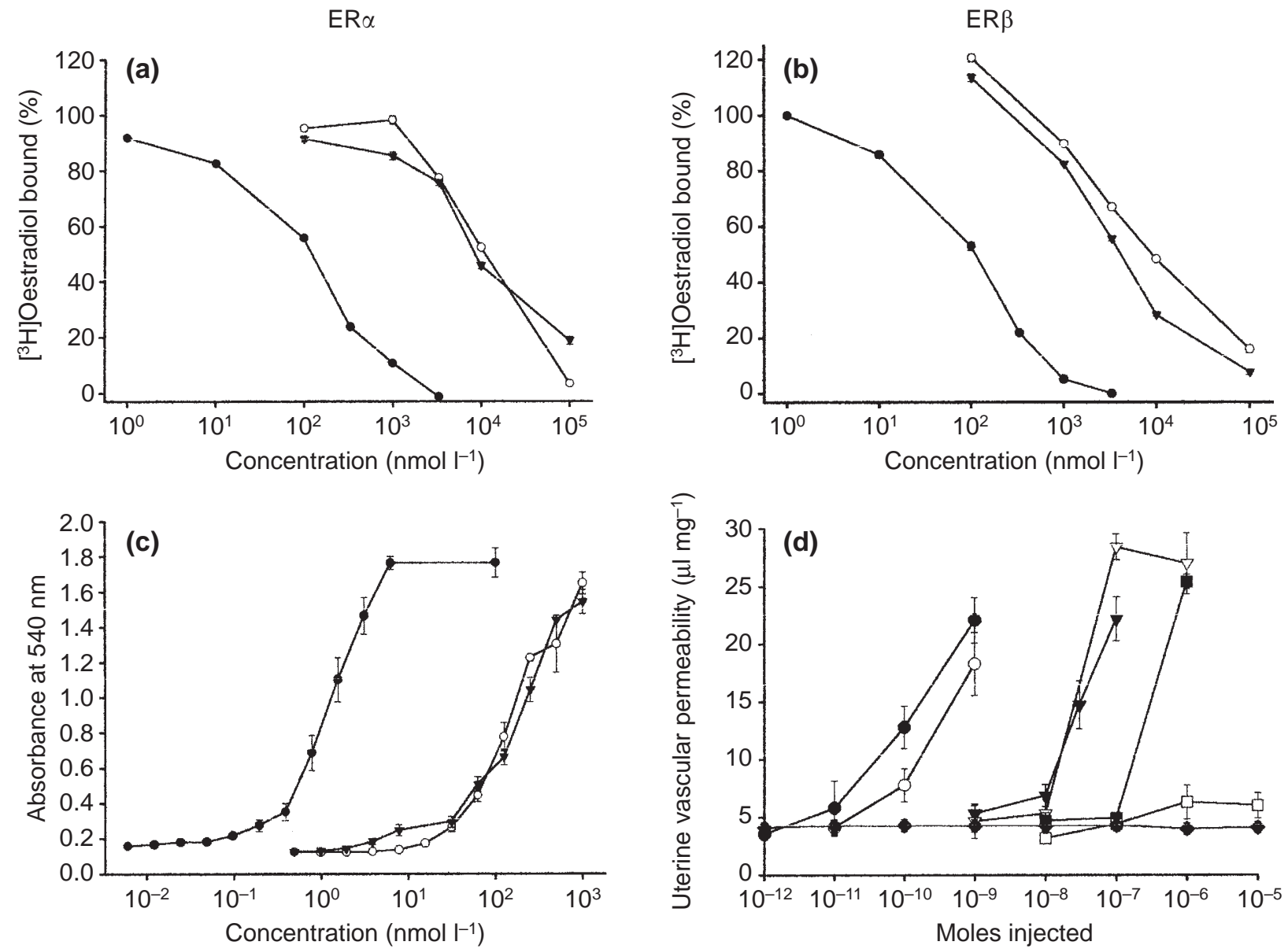

Fig. 4. Competitive displacement of $[2,4,6,7-3 \mathrm{H}]$ oestradiol from isolated (a) oestrogen receptor $\alpha(E R \alpha)$ and (b) $E R \beta$ by oestradiol $(\bullet)$ and $(R)$-8-prenylnaringenin $(\bigcirc)$ and $(S)$-8-prenylnaringenin $(\boldsymbol{\nabla})$. (c) The relative oestrogenic activity of oestradiol, $(R)$-8-prenylnaringenin and (S)-8-prenylnaringenin in the yeast screen bearing the transfected human oestrogen receptor $(n=4$; mean \pm SEM) and (d) the oestrogenic activity of oestradiol $(\bullet)$, oestriol $(\bigcirc)$, 8-prenylnaringenin $(\boldsymbol{\nabla})$, coumestrol $(\nabla)$, genistein $(\boldsymbol{\square})$ and daidzein $(\square)$, and the control $(\bullet)$ on uterine vascular permeability in ovariectomized mice $4 \mathrm{~h}$ after s.c. administration ( $n=6-10$ per treatment). Vascular permeability was expressed as $(\times 100)\left[{ }^{125}\right.$ I] c.p.m. $\mathrm{mg}^{-1}$ of tissue/[125I] c.p.m. $\mu \mathrm{I}^{-1}$ plasma (mean \pm SEM). 
Table 1. The ability of the anti-oestrogen ICI 182,780 to inhibit the increases in uterine vascular permeability (expressed as $(\times 100)[125 I]$ c.p.m. $\mathrm{mg}^{-1}$ of tissue per [125I] c.p.m. $\mu^{-1}$ plasma) induced by oestradiol and 8-prenylnaringenin

\begin{tabular}{lcc}
\hline Treatment & Uterus & Muscle \\
\hline Control (arachis oil) & $4.70 \pm 0.84$ & $0.53 \pm 0.02$ \\
ICl 182,780 pre-treatment & $4.20 \pm 0.27$ & $0.47 \pm 0.04$ \\
Oestradiol $\left(10^{-10}\right.$ mol I-1) & $12.53 \pm 1.17$ & $0.53 \pm 0.07$ \\
ICl 182,780 pre-treatment + oestradiol $\left(10^{-10} \mathrm{~mol} \mathrm{l}^{-1}\right)$ & $5.83 \pm 1.73^{* * *}$ & $0.61 \pm 0.03$ \\
8 -Prenylnaringenin $\left(10^{-7}\right.$ mol l-1) & $22.19 \pm 1.9$ & $0.54 \pm 0.02$ \\
ICl 182,780 pre-treatment +8 -prenylnaringenin $\left(10^{-7} \mathrm{~mol}^{-1}\right)$ & $5.96 \pm 0.58^{* * *}$ & $0.64 \pm 0.06$ \\
\hline
\end{tabular}

Values are mean \pm SEM.

***Significantly different compared with treatment without ICI 182, $780(P<0.001 ; n=6$ mice per treatment).

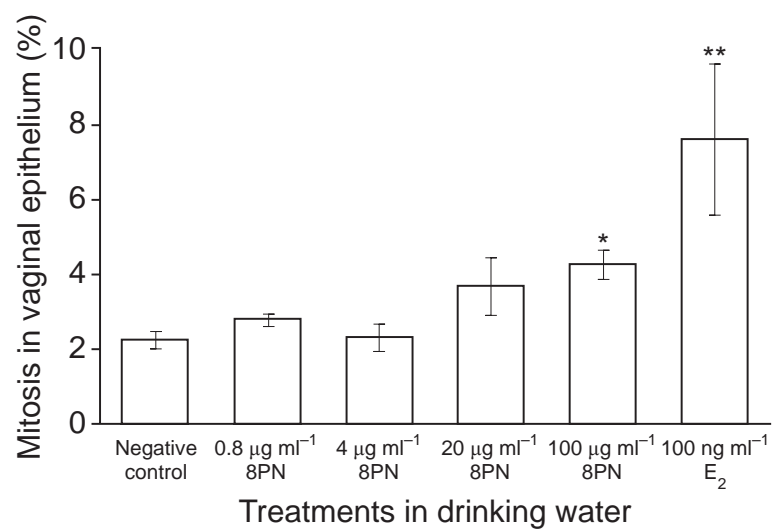

Fig. 5. Mitotic response of the vaginal luminal epithelium of ovariectomized mice to 8-prenylnaringenin (8PN) or oestradiol $\left(\mathrm{E}_{2}\right)$ administered for $72 \mathrm{~h}$ in drinking water. Data are mean \pm SEM ( $n=6$ per treatment). Significant differences are denoted by $* P<0.05,{ }^{*} P<0.005$ (Kruskal-Wallis test on ranks and Dunn's multiple comparison test).

compounds. There was little variation in the amount of liquid consumed between treatment groups $(3.72 \pm 0.26 \mathrm{ml}$ per mouse per day) and on average, $15.9 \mathrm{mg}$ 8-prenylnaringenin per $\mathrm{kg}$ per day was ingested by the treatment group that consumed the highest concentration of 8prenylnaringenin. Both 8-prenylnaringenin $\left(100 \mu \mathrm{g} \mathrm{ml}^{-1}\right)$ and oestradiol (100 $\left.\mathrm{ng} \mathrm{ml}^{-1}\right)$ produced significant increases in vaginal mitosis after $72 \mathrm{~h}$ compared with the negative control $(P<0.05$ and $P<0.005$, respectively; Fig. 5). However, although oestradiol also produced significant increases in uterine mass and in epithelial mitosis, there were no significant differences in the mice exposed to any of the 8-prenylnaringenin treatments (data not shown).

\section{Discussion}

Results from the present study confirm that 8-prenylnaringenin is one of the most potent phyto-oestrogens known to date (Milligan et al., 1999). The results from the in vitro and in vivo bioassays and oestrogen receptor binding assays in the present study and from that of Kitaoka et al. (1998) are consistent with its oestrogenic activity being considerably greater than that of genistein or daidzein. In the in vitro assays, the oestrogenic activity of 8-prenylnaringenin also slightly exceeded that of coumestrol. The apparent differences in potency of 8-prenylnaringenin between the yeast screen and the Ishikawa cell assays are consistent with similar observations comparing other compounds in these assays (Le Gueval and Pakdel, 2001).

In addition to its in vitro activity, 8-prenylnaringenin shows oestrogenic effects in vivo. 8-Prenylnaringenin induces the rapid uterine vascular response typical of oestrogens and this response is blocked by prior treatment with an anti-oestrogen. The compound has been reported to induce uterine growth and to suppress ovariectomy-induced bone loss in ovariectomized rats when administered each day s.c. at a dose of $30 \mathrm{mg}$ per $\mathrm{kg}$ per day (Miyamoto et al., 1998). In the present study, it was noted that $100 \mu \mathrm{g} 8$ prenylnaringenin $\mathrm{ml}^{-1}$ in the drinking water (equivalent to an intake of about $15 \mathrm{mg}$ per $\mathrm{kg}$ per day) was able to induce the characteristic oestrogenic mitotic response in the vaginal epithelium of ovariectomized mice. The apparent lack of effect of 8-prenylnaringenin on uterine epithelial mitoses may reflect either the limited amounts given or the temporal differences in the mitotic responses induced by oestrogens in the uterine luminal, uterine glandular and vaginal luminal epithelia (Finn and Martin, 1973; Finn and Publicover, 1981). Although it is difficult to compare the continuous exposure of mice to 8-prenylnaringenin (via oral intake) experimentally with human exposure to the compound via beer consumption, it has to be noted that the oral concentrations required to produce an oestrogenic effect in mice are about 500-fold greater than can be found in any beer (Stevens et al., 1999; Rong et al., 2000). In addition, many beers are now made using extracts from hops or hop products rather than whole hops: depending on the nature of the hop product used, these beers have even lower concentrations of 8-prenylnaringenin or contain no 8-prenylnaringenin at all (Stevens et al., 1999; Rong et al., 2000).

A number of phyto-oestrogens (for example, coumestrol, genistein) have a stronger binding affinity for ER $\beta$ than for 
ER $\alpha$ (Kuiper et al., 1997; Casanova et al., 1999), and ER $\beta$ may be an important mediator for the action of phytooestrogens. This study shows that 8-prenylnaringenin can compete with oestradiol for binding with the ER $\alpha$ and ER $\beta$, although there was no marked difference in binding affinity for the two receptors. The relative ligand binding affinities, tissue distribution and developmental pattern of expression of $E R \alpha$ and $E R \beta$ may help to explain the action of ER agonists, such as phyto-oestrogens (Brandenburger et al., 1997; Tetsuka et al., 1998). (R)- and (S)-prenylnaringenin showed comparable activities both in the in vitro bioassays and in the competitive binding assay to $E R \alpha$ and $E R \beta$. The enantiomers have also been shown to behave similarly in a competitive binding assay with uterine oestrogen receptors (Kitaoka et al., 1998).

Many natural flavanones prevail in the (S)-configuration and are formed from the corresponding chalcones as a consequence of the action of chalcone isomerase. However, the lupulin glands of hops lack chalcone isomerase and the presence of equal amounts of $(R)$ - and (S)-8-prenylnaringenin indicates that the compound may be derived from xanthohumol or desmethylxanthohumol via a non-enzymatic route (for example, thermal Michael-type cycloaddition). However, it is also possible that the precursors are converted to racemic 8-prenylnaringenin during drying, storage and extraction of hops (Stevens et al., 1999; Rong et al., 2000). The same may also be true for some other hopderived prenylated flavanones, as isoxanthohumol and 6-prenylnaringenin also occurred in both $(R)$ - and (S)-forms (data not shown). Further conversions and decompositions may occur during the brewing process and such reactions may account for the variable amounts of 8-prenylnaringenin and other prenylflavonoids found in beer (Stevens et al., 1999; Rong et al., 2000).

Although 8-prenylnaringenin has also been isolated from a crude Thai drug derived from the heartwood of Anaxagorea luzonensis A. Gray (Annonaceae) (Kitaoka, 1998), hops probably represent the most significant source of exposure of humans to the compound. In the past, hop workers would have been exposed to this oestrogenic compound via inhalation of hop dust or through transcutaneous absorption rather than via dietary intake and such exposure may provide an explanation for the menstrual disturbances in female hop workers (Verzele, 1986). The reported ability of hop extracts to reduce hot flushes in post-menopausal women (Goetz, 1990) is also consistent with the presence of oestrogenic activity. Although hops are used to impart flavour, bitterness and other properties to beer, the amount of hops used in brewing is relatively small and, therefore, 8prenylnaringenin is not a significant dietary component. However, it is important to note that hops are now incorporated into a number of herbal preparations for women, including some claiming 'breast enlargement'. Claims for the effectiveness of at least some such 'breast enlargement' preparations are partly based on their phytooestrogen content. The concentration of 8-prenylnaringenin in one type of these 'breast-enhancing' preparations is $10.9 \mu \mathrm{g} \mathrm{gm}^{-1}$, which would result in a daily intake of approximately $130 \mu \mathrm{g}$ per day (Sauer and Coldham, 2001). This value should be compared with the fact that some beers have been reported to contain concentrations of $240 \mu \mathrm{g}$ 8-prenylnaringenin $\mathrm{I}^{-1}$ (although most are below $30 \mathrm{\mu g} \mathrm{I}^{-1}$; Stevens et al., 1999). Therefore, although moderate beer intake could provide a daily intake of 8-prenylnaringenin in the same range as that provided by some 'breast enhancement' products, it should be noted that there are no reports of clinical trials demonstrating either the effectiveness or oestrogenic activity of such herbal preparations in humans. Indeed, Sauer and Coldham (2001) found that the supplement tested was inactive in a mouse uterotrophic assay after administration either in the feed or by s.c. injection. In addition, the present study showed that the concentrations of 8-prenylnaringenin required to produce oestrogenic responses in mice are $100 \mu \mathrm{g} \mathrm{ml}^{-1}$, that is, at least 400-fold greater than found in any beer. Finally, although there may be interactions between alcohol intake and the risk of breast cancer (Hulka and Moorman, 2001), there is no evidence linking beer intake with breast enhancement. Other biological activities of 8prenylnaringenin have been described, including antiproliferative effects on breast and colon cancer cell lines, inhibition of cytochrome P450-mediated activation of procarcinogens, inhibition of bone resorption and inhibition of diacylglycerol acyltransferase activity (Miranda et al., 1999; Henderson et al., 2000). The biological effects, if any, of consumption of 8-prenylnaringenin via beer or herbal preparations remain to be clarified.

The authors are grateful to The Leverhulme Trust and to The Royal Society for supporting this work.

\section{References}

Arvidson NG (1977) Early estrogen-induced changes in uterine albumin exchange in mice Acta Physiologica Scandinavica $100325-331$

Brandenberger AW, Tee MK, Lee JY, Chao V and Jaffe RB (1997) Tissue distribution of estrogen receptors alpha (ER-alpha) and beta (ER-beta) mRNA in the mid-gestational human fetus Journal of Clinical Endocrinology and Metabolism 82 3509-3512

Casanova M, You L, Gaido KW, Archibeque-Engle S, Janszen DB and Heck HA (1999) Developmental effects of dietary phytoestrogens in Sprague-Dawley rats and interactions of genistein and daidzein with rat estrogen receptors alpha and beta in vitro. Toxicological Sciences $\mathbf{5 1}$ 236-244

Cassidy A and Milligan SR (1998) How significant are environmental estrogens to women? Climacteric 1 1-12

Fenselau C and Talalay P (1973) Is estrogenic activity present in hops? Food and Cosmetics Toxicology 11 597-603

Finn CA and Martin L (1973) Endocrine control of gland proliferation in the mouse uterus Biology of Reproduction 8 585-588

Finn CA and Publicover M (1981) Hormonal control of cell death in the luminal epithelium of the mouse uterus Journal of Endocrinology 91 $335-340$

Gaffield W (1970) Circular dichroism, optical rotatory dispersion and absolute configuration of flavanones, 3-hydroxyflavanones and their glycosides Tetrahedron 26 4093-4108

Goetz P (1990) Traitement des bouffées de chaleur par insuffisance 
ovarienne par l'extrait de houblon (Humulus lupulus). Revue de Phytothérapie Pratique 4 13-15

Henderson MC, Miranda CL, Stevens JF, Deinzer ML and Buhler DR (2000) In vitro inhibition of human P450 enzymes by prenylated flavonoids from hops, Humulus lupulus. Xenobiotica $30235-251$

Hesse R, Hoffman B, Karg H and Vogt K (1981) Untersuchungen über den Nachweis von Phytoöstrogenen in Futterpflanzen und Hopfen mit Hilfe eines Rezeptortests Zentralblatt fur Veterinärmedizin 28 422-454

Hulka BS and Moorman PG (2001) Breast cancer: hormones and other risk factors Maturitas 38 103-113

Kitaoka M, Kadokawa H, Sugano M et al. (1998) Prenylflavonoids: a new class of non-steroidal phytoestrogens (Part 1). Isolation of 8isopentenylnaringenin and an initial study on its structure-activity relationship Planta Medica 64 511-515

Knight DC and Eden JA (1996) A review of the clinical effects of phytoestrogens Obstetrics and Gynecology 87 897-904

Koch W and Heim G (1953) Hormone in hopfen und bier Brauwissenschaft 8 132-133

Kuiper GGJM, Carlsson B, Grandien K, Enmark E, Haggblad J, Nilsson S and Gustafsson JA (1997) Comparison of the ligand binding specificity and transcript tissue distribution of estrogen receptors alpha and beta Endocrinology 138 863-870

Le Gueval R and Pakdel F (2001) Assessment of oestrogenic potency of chemicals used as a growth promoter by in vitro methods Human Reproduction 16 1030-1036

Markiewicz L, Garey J, Adlercreutz H and Gurpide E (1993) In vitro bioassays of non-steroidal phytoestrogens Journal of Steroid Biochemistry and Molecular Biology 45 399-405

Milligan SR, Balasubramanian AV and Kalita JC (1998) Relative potency of xenobiotic oestrogens in an acute in vivo mammalian assay Environmental Health Perspectives 106 23-26

Milligan SR, Kalita JC, Heyerick A, Rong H, De Cooman L and De Keukeleire D (1999) Identification of a potent phytoestrogen in hops (Humulus lupulus L.) and beer Journal of Clinical Endocrinology and Metabolism 83 2249-2252
Miranda CL, Stevens JF, Helmrich A, Henderson MC, Rodriguez RJ, Yang YH, Deinzer ML, Barnes DW and Buhler DR (1999) Antiproliferative and cytotoxic effects of prenylated flavonoids from hops (Humulus lupulus) in human cancer cell lines Food and Chemical Toxicology 37 271-285

Miyamoto M, Matsushita Y, Kiyokawa A, Fukuda C, lijima Y, Sugano M and Akiyama T (1998) Prenylflavonoids: a new class of non-steroidal phytoestrogens (Part 2). Estrogenic effects of 8-isopentenylnaringenin on bone metabolism Planta Medica 64 516-519

Rong H, Zhao Y, Lazou K, De Keukeleire D, Milligan SR and Sandra P (2000) Quantitation of 8-prenylnaringenin, a novel phytoestrogen in hops (Humulus lupulus L.), hop products and beers, by benchtop HPLC using electrospray ionization Chromatographia 51 545-552

Routledge EJ and Sumpter JP (1996) Estrogenic activity of surfactants and some of their degradation products assessed using a recombinant yeast screen Environmental Toxicology and Chemistry 15 241-258

Sauer MJ and Coldham NG (2001) Phyto-oestrogen content and oestrogenic activity of a hop-containing food supplement Reproduction Abstracts Series 2715

Stevens JF, Taylor AW and Deinzer ML (1999) Quantitative analysis of xanthohumol and related prenylflavonoids in hops and beer by liquid chromatography-tandem mass spectrometry Journal of Chromatography A 832 97-107

Tetsuka M, Milne M and Hillier SG (1998) Expression of oestrogen receptor isoforms in relation to enzymes of oestrogen synthesis in rat ovary Molecular and Cellular Endocrinology 141 29-35

Verzele M (1986) 100 years of hop chemistry and its relevance to brewing Journal of the Institute of Brewing 92 32-48

Zenisek A and Bednar IJ (1960) Contribution to the identification of estrogen activity in hops American Perfumer Aromatics 75 61-62

Received 13 September 2001.

First decision 16 October 2001.

Accepted 2 November 2001. 